\title{
Spatial Decision Assistance of Watershed Sedimentation (SDAS): Development and Application
}

\author{
Poerbandono $^{1}$ *, Agung B. Harto ${ }^{1} \&$ Miga M. Julian ${ }^{2}$ \\ ${ }^{1}$ Coastal and Ocean Zone System and Engineering Science Research Division, \\ Faculty of Earth Sciences and Technology, Institut Teknologi Bandung, \\ Jalan Ganesa No. 10, Bandung 40132, Indonesia \\ ${ }^{2}$ Institut für Geographie, Lehrstuhl für Geoinformatik, \\ Geohydrologie und Modellierung, Friedrich-Schiller-Universität, \\ Löbdergraben 32, Jena, 07743, Germany \\ *Email: poerbandono@gd.itb.ac.id
}

\begin{abstract}
This paper discusses the development and application of a spatial tool for erosion modeling named Spatial Decision Assistance of Watershed Sedimentation (SDAS). SDAS computes export (yield) of sediment from watershed as product of erosion rate and sediment delivery ratio (SDR). The erosion rate is calculated for each raster grid according to a digital elevation model, soil, rain fall depth, and land cover data using the Universal Soil Loss Equation. SDR calculation is carried out for each spatial unit. A spatial unit is the smallest sub-watershed considered in the model and generated according to the TauDEM algorithm. The size of one spatial unit is assigned by the user as the minimum number of raster grids. SDR is inversely proportional to sediment resident time and controlled by rainfall, slope, soil, and land cover. Application of SDAS is demonstrated in this paper by simulating the spatial distribution of the annual sediment yield across the Citarum watershed in the northwest of Java, Indonesia. SDAS calibration was carried out based on sediment discharge observations from the upper catchment. We considered factors for hillslope flow depth and for actual and effective rainfall duration to fit the computed sediment yield to the observed sediment discharge. The computed sediment yield agreed with the observation data with a $7 \%$ mean relative accuracy.
\end{abstract}

Keywords: decision support; sediment delivery ratio; sediment yield; spatial erosion.

\section{$1 \quad$ Introduction}

With the increase of global air temperature, excessive precipitation is expected to intensify primarily in tropical regions $[1,2]$. This may result in amplification of the risk of flooding due to surface erosion [3]. Erosion in upper watershed regions can reduce drainage capacity in lower regions, which, combined with increasing runoff, intensifies the risk of flooding [4,5]. In response to such a risk, proper adaptation plans must be made available. Absence of proper adaptation plans may result in rapid exacerbation of damages due to flooding [6]. Adaptation plans are often irreversible [7]. Therefore, thorough scientific

Received September $17^{\text {th }}, 2012$, Revised July $11^{\text {th }}, 2013$, Accepted for publication January $30^{\text {th }}, 2014$.

Copyright (C) 2014 Published by ITB Journal Publisher, ISSN: 2337-5779, DOI: 10.5614/j.eng.technol.sci.2014.46.1.3 
study in selecting adaptation plans is required to ensure success of reducing risks. Scientific works related to quantification of surface erosion are mostly complex and laborious. Conversely, regulators often require immediate information on projected risks with considerable reliability. This will allow them to review the relevance and impact of any established plan in order to minimize the risk of hydrologic disaster [8]. In recent years, various tools dedicated to watershed studies have been developed that can provide support for decision-making in accordance with spatial planning for reduction of watershed erosion [9-12]. Most of the present quantifications of information about erosion in spatially distributed zones rely on computer simulation $[13,14]$. The work by Arnold, et al. [15], to name one, is a comprehensive watershed simulation tool that involves hydrology, weather, sedimentation, soil temperature, crop growth, nutrients, pesticides, and agricultural management.

Computer simulation for studying watershed erosion is beneficial as it offers cost-effectiveness, repeatability, and capability of considering what-if conditions, i.e. what output may result if a particular input is altered. Most tools for erosion simulation are facilitated by commercially licensed software or, if it is license-free, must be developed by people having expertise in programming as well as hydrology. The present work fills a gap in the existing erosion simulation tools by delivering a license-free computer application for academic training and educational purposes at the undergraduate level, such as class teaching and student assignments. This paper discusses the development and application of a tool for computing and geographically locating erosion and sediment yield in a watershed. The tool being developed-as presented in this paper-is named Spatial Decision Assistance of Watershed Sedimentation (SDAS). It integrates a sequence of equations that represent the physical processes of sediment detachment, transport, and deposition through a watershed's surface. The equations are applied to each spatial unit. A spatial unit is the smallest sub-watershed consisting of at least one section of reach catchment considered in the spatial model of a river basin. SDAS includes a spatial unit generator and user interface. The application of SDAS is demonstrated in this paper by simulating the sediment yield of the Citarum watershed in the northwest of Java. Results from SDAS computation were calibrated against observed sediment yield data from Nanjung station at the upper Citarum watershed.

\section{$2 \quad$ Materials and Methods}

\subsection{Estimation of Sediment Yield}

Sediment yield $(y)$ refers to the discharge of sediment exported out from a watershed, which is usually evaluated per annum and expressed in tons per year. 
Sediment yield is a product of erosion $(e)$ throughout the watershed surface and efficiency of the watershed in transporting sediment from the source of erosion, or the sediment delivery ratio (SDR):

$$
y=e \cdot \mathrm{SDR}
$$

A process-based approach of SDR estimation has been proposed by Lu, et al. [16], which was used here as a primary reference for sediment yield simulation. While the rate of erosion $(e)$ can be directly estimated using the Universal Soil Loss Equation (USLE) [17], estimation of the SDR requires several steps that consider the transport mechanism of sediment particles through the watershed surface. SDR estimation in SDAS is based on a concept proposed by Sivapalan, et al. [18]. It divides a drainage basin into so-called hillslope storage $(h)$ and network channel storage $(n)$. Figure 1(a) illustrates the sediment originated from erosion exported out from a watershed through the final outlet $(y)$ and the SDR across the entire hillslope and channel networks calculated in each of the spatial units that are considered as sub-watersheds (Figure 1(b)).

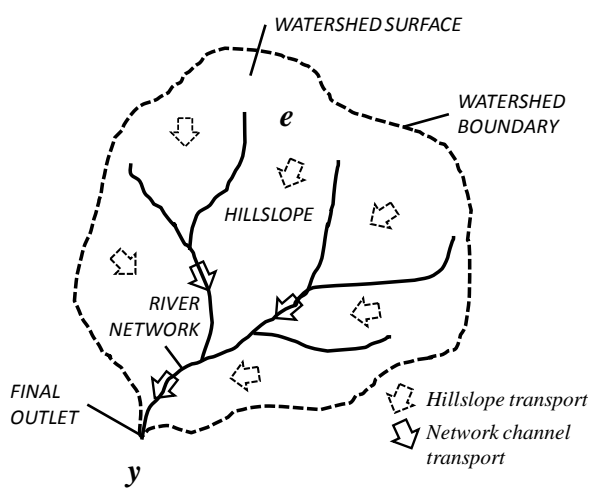

(a) Hillslope and channel network transport

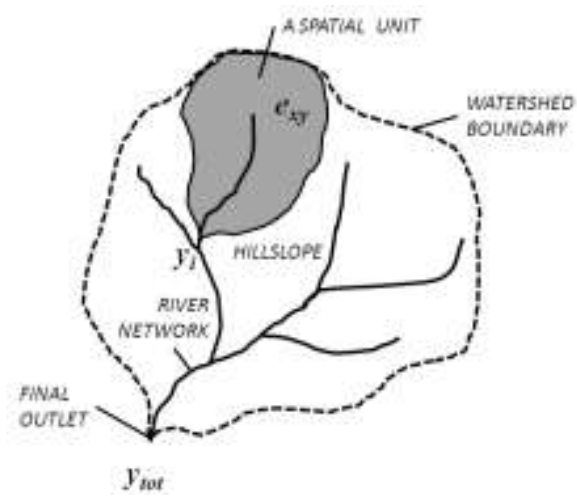

(b) Spatial unit representing sub-watershed

Figure 1 Conceptual visualization of total yield of sediment from a watershed.

\subsubsection{Sediment Delivery Ratio}

Estimation of SDR in SDAS is operated according to the analytical solution of a time-dependent equation expressing storage of sediment in the hillslope and channel network as developed by Sivapalan, et al. [18], which is a function of sediment resident time in the hillslope $\left(t_{h}\right)$, sediment resident time in the channel network $\left(t_{n}\right)$, and effective rainfall duration $\left(t_{e r}\right)$ :

$$
\left.\mathrm{SDR}=\frac{t_{n}}{t_{n}-t_{h}}\left(1-e^{\left(-t_{c o r} / t_{n}\right.}\right)\right)-\frac{t_{n}}{t_{n}-t_{h}}\left(1-e^{\left(t_{c o t} / t_{h}\right)}\right), \text { for } t_{n} \neq t_{h}
$$




$$
\mathrm{SDR}=\frac{1}{2}\left(\frac{t_{e r}^{2}}{t_{n}^{2}}\right)+\frac{1}{3}\left(\frac{t_{e r}^{3}}{t_{n}^{3}}\right)+\ldots, \text { for } t_{n}=t_{h}
$$

Eqs. (2a) and (2b) consider the inversely proportional relation between SDR and sediment resident time, both in the hillslope $\left(t_{h}\right)$ and in the channel network $\left(t_{n}\right)$ $[18,19]$. This implies that the longer the sediment resident time is, the smaller the SDR. Due to this, the yield of sediment $(y)$ will hence be smaller. The role of the sediment resident time in governing the SDR is based on the basic relationship between travel time, travel speed of the water flow that transports the sediment particles from the source of erosion, and travel distance:

$$
\begin{array}{ll}
t_{h w}=\frac{D}{V_{h}} & \text { in the hillslope } \\
t_{n w}=\frac{D}{V_{n}} & \text { in the network channel }
\end{array}
$$

with $t_{h w}=$ travel time of water flow in the hillslope, $t_{n w}=$ travel time of water flow in the channel network, $V_{h}=$ travel speed of water flow in the hillslope, $V_{n}$ $=$ travel speed of water flow in the channel network, and $D=$ travel distance in the watershed surface model, i.e. digital elevation model (DEM). As $D$ can be obtained from the DEM used for the watershed surface model, $t_{h w}$ and $t_{n w}$ can be calculated according to $V_{h}$ and $V_{n}$ as:

$$
\begin{aligned}
& V_{h}=\frac{\left(i_{e} L\right)^{0.4} s^{0.3}}{n^{0.6}} \\
& V_{n}=a s^{0.5}
\end{aligned}
$$

with $i_{e}=$ rainfall excess rate, $L=$ travel distance along the flow path, $s=$ decimal slope, $n=$ Manning's roughness coefficient, and $a=$ streambed roughness coefficient. The excess rate of rainfall $i_{e}$ is calculated as:

$$
i_{e}=\frac{P_{e}}{t_{r}}
$$

with $t_{r}=$ average rainfall duration and $P_{e}=$ rainfall excess depth, where:

$$
P_{e}=\frac{(P-0.2 S)^{2}}{(P+0.8 S)}
$$

with $P=$ actual, observed, or known rainfall depth and $S=$ land cover dependent storage term: 


$$
S=\frac{254}{C N} 100-254
$$

with $C N=$ land cover variability number, obtained according to:

$$
C N=\frac{\sum_{i=1}^{m} C N_{i} A_{i}}{\sum_{i=1}^{m} A_{i}}
$$

with $i=$ sub-area (inside spatial unit) having a particular type of land cover, $m=$ number of sub-areas, $C N_{i}=$ number representing water storage capacity for a particular type of soil, and $A_{i}=$ size of pixels covering a sub-area, i.e. areas with similar $C N_{i}$. A look-up table for $C N_{i}$ is given in Table 1 . The numbers in the header $(0,1,2,3)$ of Table 1 represent a code for the group of soil type.

Table $1 \quad C N[20]$.

\begin{tabular}{lrrrr}
\hline \multirow{2}{*}{ Types of Land Use } & \multicolumn{4}{c}{$\boldsymbol{C N}$} \\
\cline { 2 - 6 } & $\mathbf{0}$ & $\mathbf{1}$ & $\mathbf{2}$ & $\mathbf{3}$ \\
\hline Residential & 49 & 69 & 79 & 84 \\
Shrub, pastures, park & 48 & 67 & 77 & 83 \\
Forest & 30 & 55 & 70 & 77 \\
Farm, garden, dry field & 72 & 81 & 88 & 81 \\
Aquatic vegetation / wetland & 66 & 74 & 80 & 82 \\
River / pond / lake & 98 & 98 & 98 & 98 \\
\hline Note: 0 for andosol, grumosol, podsol, podsolic; 1 for latosol; 2 for regosol, litosol, \\
organosol, renzina, mediteran; 3 for alluvial, planosol, grey hydromorph, lateric.
\end{tabular}

Table 2 Manning's roughness coefficient [16].

\begin{tabular}{llll}
\hline \multirow{2}{*}{ Land Use } & \multicolumn{3}{c}{ Vegetation Cover $\left(\boldsymbol{C}_{\boldsymbol{v}}\right)$ in \% } \\
\cline { 2 - 4 } \multicolumn{1}{c}{$\boldsymbol{C}_{\boldsymbol{v}}<\mathbf{3 0}$} & $\mathbf{3 0}<\boldsymbol{C}_{\boldsymbol{v}}<\mathbf{7 0}$ & $\boldsymbol{C}_{\boldsymbol{v}}>\mathbf{7 0}$ \\
\hline Pasture & 0.15 & 0.4 & 0.6 \\
Crop & 0.15 & 0.25 & 0.4 \\
Forest & 0.2 & 0.6 & 0.8 \\
Built-up areas & 0.1 & 0.3 & 0.5 \\
Wetland and ponds & 0.125 & 0.125 & 0.125 \\
\hline
\end{tabular}

Table 3 Channel roughness parameter [16].

\begin{tabular}{lcc}
\hline \multicolumn{1}{c}{ Channel section } & $\begin{array}{c}\text { Upstream area } \\
\text { (Ha) }\end{array}$ & $\boldsymbol{A}$ \\
\hline Concentrated shallow flow & $1.8-18$ & 4 \\
Intermittent stream & $18-360$ & 4.5 \\
Permanent stream & $>360$ & 5 \\
\hline
\end{tabular}


Manning's roughness coefficient $n$ is given to Eq. (4a) according to the generic type of land use and percentage of vegetation cover $\left(C_{v}\right)$ as shown in Table 2. The values for channel network flow speed $a$ used by Eq. (4b) are given in Table 3.

Sediment residence time is obtained from travel time of water flow. In the hillslope, the sediment residence time $\left(t_{h}\right)$ is calculated according to travel time of water flow $\left(t_{h w}\right)$ and a multitude function $\left(F_{h}\right)$. Similarly, in the channel network, the sediment residence time $\left(t_{n}\right)$ is calculated according to travel time of water flow $\left(t_{n w}\right)$ and a multitude function $\left(F_{n}\right)$ :

$$
\begin{aligned}
& t_{h}=t_{h w} F_{h} \\
& t_{n}=t_{n w} F_{n}
\end{aligned}
$$

with $t_{h w}=$ travel time of water flow across hillslope and $t_{n w}=$ travel time of water flow across channel network. $F_{h}$ and $F_{n}$ are the multitude functions:

$$
\begin{aligned}
& F_{h}=e^{\left(\gamma_{h} w_{s}\right)} \\
& F_{n}=e^{\left(\gamma_{n} w_{s}\right)}
\end{aligned}
$$

with $w_{s}=$ falling velocity of sediment in the water column. $\gamma_{h}$ and $\gamma_{n}$ respectively describe depth of water flow across hillslope $\left(h_{h}\right)$ and depth of water flow across channel network $\left(h_{n}\right)$, in which $\gamma_{h}=h_{h}-1$ and $\gamma_{n}=h_{n}-1$. The velocity of sediment settling is calculated as:

$$
w_{s}=\left(\frac{4 \rho_{s} g d}{3 \rho C_{D} R_{e p}}\right)^{\frac{1}{2}}
$$

with $\rho_{s}=$ density of sediment, $\rho=$ density of water, $g=$ acceleration due to gravity, $d=$ sediment size, and $R_{e p}=w_{s} d / v . R_{e p}$ is the Reynolds' number for the given settling velocity and sediment grain size being a function of water kinematics viscosity $(v)$ and drag coefficient $\left(C_{D}\right)$. Drag coefficient $\left(C_{D}\right)$ reads as:

$$
C_{D}=\frac{24}{R_{e p}}\left(1+0.15 R_{e p}{ }^{0.687}\right)
$$




\subsubsection{Rate of Erosion}

SDAS utilizes USLE as proposed by Wischmeier \& Smith [17] for estimating the rate of erosion $(e)$. USLE considers the empirical relation between $e$ and the slope index $\left(L_{S}\right)$, land cover $(C)$, erodibility $(K)$, and erosivity $(R)$ :

$$
e=L_{S} C K R
$$

Slope index $L_{S}$ is obtained from the DEM [17]:

$$
L_{S}=\left(\frac{L}{k}\right)^{b}\left(k_{1} \sin ^{2} s+k_{2} \sin s+k_{3}\right)
$$

In Eq. (14), $b$ accounts for slope index, $s$ is slope in percent, and $L$ is length of sloping profile [21], where $b=0.2$ for $0 \leq s<1, b=0.3$ for $1 \leq s<3, b=0.4$ for $3 \leq s<4.5$ and $b=0.5$ for $s \geq 4.5$, and $k$ is a series of constants, i.e. $k=22.1, k 1$ $=65.41, k 2=4.56$ and $k 3=0.065$. The type of land cover $(C)$ is ranked and grouped according to exposure and can be obtained from a look-up table (Table 4). Erodibility $(K)$ indicates mobility of sediment particles due to detachment by kinetic energy generated by raindrops and transport by surface runoff. It can be seen as sediment resistance from movement, which can be influenced by properties of the soil, including texture, stability, infiltration and content, both organic and chemical. Determination of $K$ follows a look-up table (Table 5).

Table 4 Land cover value [22].

\begin{tabular}{ll}
\hline \multicolumn{1}{c}{ Land cover type } & \multicolumn{1}{c}{$\boldsymbol{C}$} \\
\hline Rivers / ponds / lakes & 0.0001 \\
Industrial zone & 0.0005 \\
Residential & 0.0007 \\
Aquatic vegetation / wetland & 0.001 \\
Forest & 0.002 \\
Shrub, pastures, park & 0.003 \\
Farm, garden, dry field & 0.005 \\
Open land & 0.4 \\
Mining zone & 0.7 \\
\hline
\end{tabular}

Table 5 Erodibility [23,24].

\begin{tabular}{lcc}
\hline \multicolumn{1}{c}{ Soil type } & $\boldsymbol{K}$ & Code \\
\hline Alluvial, planosol, grey hydromorph, lateric & 0.20 & 3 \\
Latosol & 0.23 & 1 \\
Mediteran & 0.24 & 2 \\
Andosol, grumosol, podsol, podsolic & 0.26 & 0 \\
Regosol, litosol, organosol, renzina & 0.31 & 2 \\
\hline
\end{tabular}


Erosivity $(R)$ represents external forcing generated by rainfall to detach sediments from the soil surface. $R$ is expressed as a function of rainfall depth $P$ [25]:

$$
R=2.21 P^{1.36}
$$

with $P=$ monthly rainfall depth.

\subsection{Computation Sequence}

SDAS is constructed from five primary components: terrain, storage, erosion rate, SDR, and sediment yield. The terrain component facilitates generation of a sink-free DEM, which is used by the erosion rate component for carrying out a calculation for each grid cell. Output from the terrain component is also used by the storage component to generate the spatial unit (see: Figure 1(b)). The process of defining a spatial unit is critical, as it provides the basis for the virtual extent of the area inside the watershed for the calculation of the SDR. The spatial unit also indicates the resolution of the SDR and sediment yield computation. In optimizing the trade-off between model resolution and computing effort, a spatial unit should contain several grids or a river of order greater than one. Here, we applied the TauDEM algorithm [26] to delineate a spatial unit that consists of several grids. In the spatial unit, all grids containing a river of order greater than one are defined as channel network element, whereas the remaining grids are defined as hillslope element. In Figure 2, a flow diagram is given of how SDAS operates when implementing details of the components of the model.

In Figure 3 the generation of hillslope and channel network from a sink-free DEM is shown. The flow direction is defined throughout the DEM, being the steepest descent from a grid to its eight surrounding grids [27]. The network of flow directions is then constructed, contributed by all grids. The numbering of the river order in the network can hence be applied and for this particular purpose we use the numbering from Strahler [28] and Strahler [29]. The highest river order number is connected to all contributing flow directions of the subwatershed, whereas a river order of one means a grid with one flow direction, which is considered a hillslope. Consequently, the river network would then be the rest of the raster grids in the computation domain, i.e. grey and black grids.

Calculation of SDR is done by averaging travel time of water flow (from source of erosion to sub-catchment outlet) through the flow path within a spatial unit. This requires identification of the extent of the hillslope and the length of the river network in the computation domain. The yield of sediment exported out from the watershed $\left(y_{t o t}\right)$ through the final outlet is the total accumulation of sediment produced by all spatial units in the watershed model: 


$$
y_{t o t}=\sum y_{i}
$$

with $i=$ spatial unit and $y_{i}=$ yield of sediment exported from a sub-watershed (represented by the corresponding spatial unit) being the product of total rate of erosion and average $\mathrm{SDR}$ inside that spatial unit (i.e. $\mathrm{SDR}_{i}$ ):

$$
y_{i}=\sum e_{x y} \mathrm{SDR}_{i}
$$

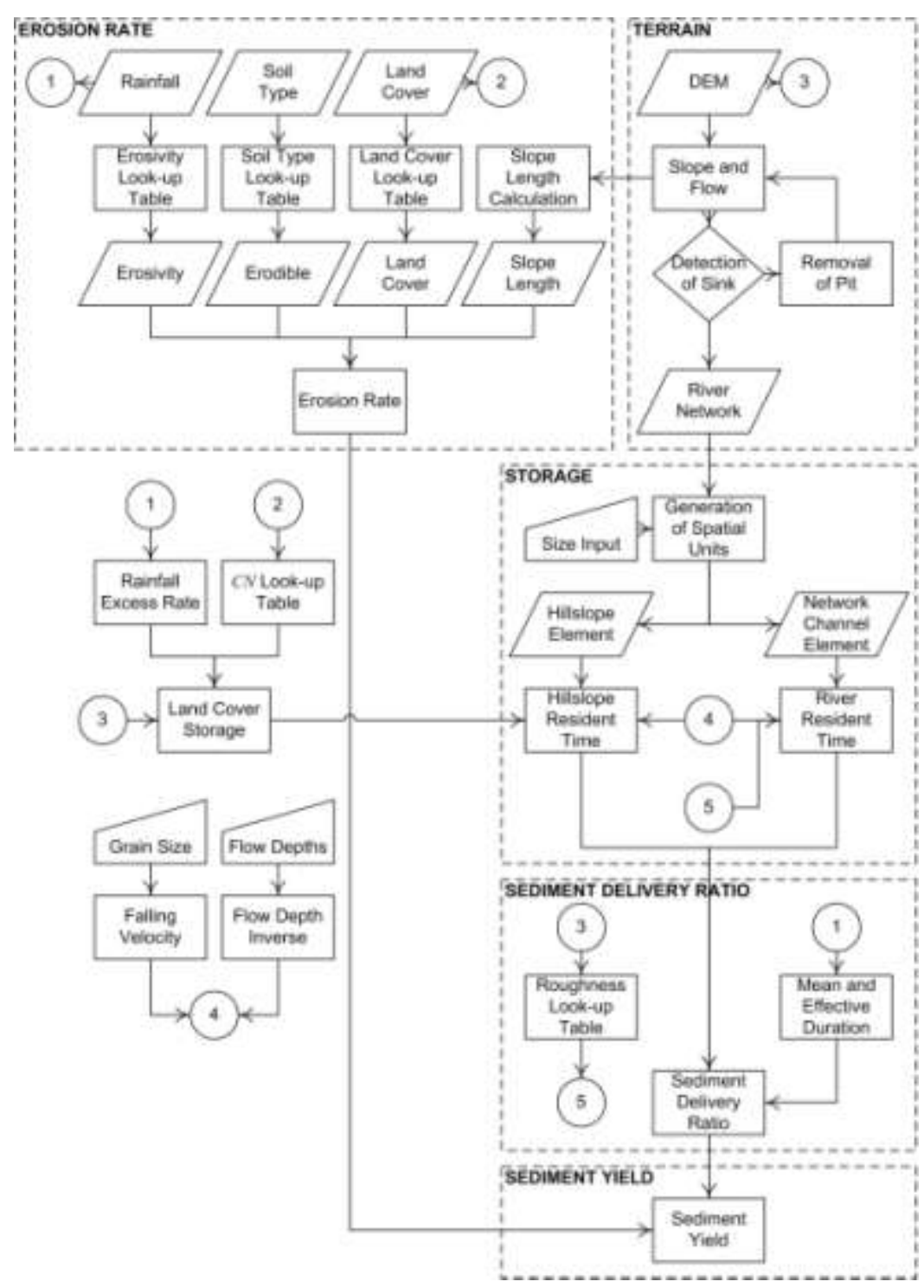

Figure 2 SDAS operation flow diagram. 


\begin{tabular}{|l|l|l|l|l|}
\hline 89 & 83 & 85 & 80 & 88 \\
\hline 81 & 84 & 77 & 79 & 75 \\
\hline 85 & 79 & 75 & 71 & 73 \\
\hline 78 & 77 & 67 & 59 & 53 \\
\hline 76 & 63 & 57 & 55 & 47 \\
\hline
\end{tabular}

(a) DEM

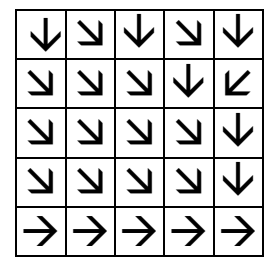

(b) Flow direction

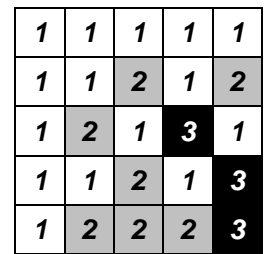

(c) River order

Figure 3 Sequence of generation of hillslope and channel network model.

\subsection{Sensitivity Test and Data Input}

Calculation of USLE and SDR requires several input maps (i.e. rainfall, soil type, distribution of land cover, and topography or DEM) and information on the physical properties of flow depth and sediment size. Information on the physical properties of flow depth and sediment size must be assumed. Experience in applying the same method for estimating $y$ and SDR [19] suggests a sediment size of $80 \mu \mathrm{m}$ with a corresponding settling velocity of 0.09 $\mathrm{m} / \mathrm{s}$. This is based on the assumption that the watershed surface is entirely covered by fine sand material. Furthermore, we also initially assumed that the height of flow is $0.025 \mathrm{~m}$ for hillslopes and $1 \mathrm{~m}$ for network channels. Additional approximation is expected for determining average rainfall duration $\left(t_{r}\right)$ and effective rainfall duration $\left(t_{e r}\right)$. It has been proposed in [19] that average and effective rainfall duration are directly proportional to mean annual rainfall (MAR). An investigation of the relationship between MAR with the corresponding rainfall duration and effective rainfall has been documented in [30]. It was shown that with a MAR ranging from 250 to $1500 \mathrm{~mm}$, the range of total average rainfall duration and effective rainfall duration per month is between 7.5 and 25 hours. Here, it is assumed that erosion occurs during the entire effective rainfall duration. In this work we used a DEM extracted from Advanced Space-borne Thermal Emission and Reflection Radiometer Global DEM (ASTER GDEM) data [31], which are available in a spatial resolution of $30 \mathrm{~m} \times 30 \mathrm{~m}$ (Figure 4).

A sensitivity test of the SDAS output (i.e. sediment yield) due to changes in inputs and key-in constants was carried out. SDAS calculation considers changes in land cover and precipitation, while assuming DEM and soil type to be constant. These inputs, i.e. land cover and precipitation, are the primary concern in a practical sense in order to evaluate the impact of climate (represented by precipitation) and human activity (represented by land cover) in controlling the alteration of erosion behavior on watersheds. Key-in constants comprise of flow depth (across hillslopes and channel networks $-h_{h}$ and $h_{n}$ ), sediment settling velocity $\left(w_{s}\right)$, rainfall duration $\left(t_{r}\right)$ and effective rainfall 
duration $\left(t_{e r}\right)$. We ran SDAS with half, once, and twice the values of the inputs and constants $(\chi)$, and then evaluated the resulted sediment yields $(y=\mathrm{f}(\chi))$.

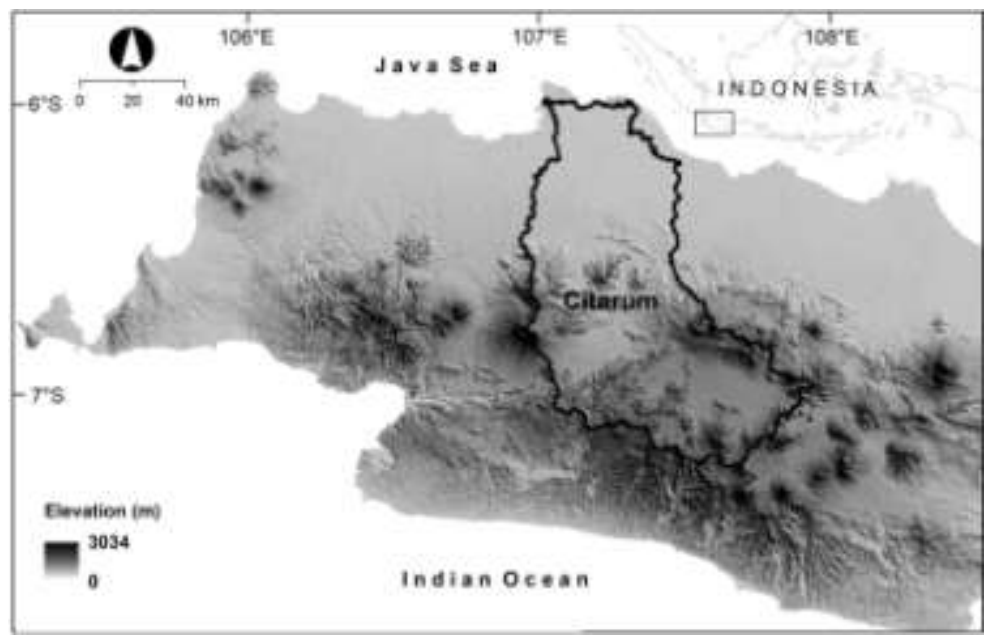

Figure 4 Digital elevation model of the study area.

Table 6 shows the results from the sensitivity test. From Table 6, one may learn that calculation of sediment yield performed by SDAS is sensitive to hillslope flow depth and settling velocity, and slightly sensitive to precipitation, land cover, and effective rainfall. Changes in hillslope flow depth $\left(h_{h}\right)$ are directly proportional to sediment yield magnitude. Increasing and lowering $h_{h}$ by a factor of 2 means sediment yield is increased by 1 order of magnitude and lowered by 3 orders of magnitude, respectively. Changes in sediment settling velocity $\left(w_{s}\right)$ are indirectly proportional to magnitude of sediment yield. Increasing and lowering $w_{s}$ by a factor of 2 means sediment yield is increased by roughly 1 order of magnitude and lowered by almost 3 orders of magnitude, respectively. Precipitation $(P)$ and land cover $(C)$ are directly proportional to magnitude of sediment yield. Changing $P$ and $C$ by a factor of 2 gives triple and double sediment yield magnitudes, respectively.

Table 6 Sensitivity test results.

\begin{tabular}{lllll}
\hline \multirow{2}{*}{ Type } & & \multicolumn{3}{c}{$\boldsymbol{y = f}(\chi)$} \\
\cline { 3 - 5 } & & $\mathbf{0 . 5} \chi$ & $\chi$ & \multicolumn{1}{c}{$\mathbf{2} \chi$} \\
\hline Input & $P$ & 0.27 & 1 & 3.54 \\
& $C$ & 0.557 & 1 & 2.229 \\
\hline Constant & $h_{n}$ & 1 & 1 & 1 \\
& $h_{h}$ & 0.003 & 1 & 9.17 \\
& $w_{s}$ & 9.17 & 1 & 0.002 \\
& $t_{r}$ & 1.31 & 1 & 0.77 \\
& $t_{e r}$ & 0.5 & 1 & 2 \\
\hline
\end{tabular}


Application of SDAS is presented by simulating $e$, SDR, and $y$ across the entire Citarum watershed on Java Island, Indonesia. The modeling period covers the early 20th century until the beginning of the 21 st century on an annual basis, i.e. from 1901 to 2005. The land cover data originate from various sources (Table 7). The global precipitation time-series dataset covering a century record (i.e. 1901-2005) is available from the Climatic Research Unit (CRU), University of East Anglia, United Kingdom [32]. The CRU provides a gridded set of monthly climate reanalysis data for the entire globe at a $30^{\prime} \times 30^{\prime}$ resolution. In addition to that, climatology data from the same source (i.e. CRU) were also used. These show the mean monthly temperature and precipitation for the same period at a higher spatial resolution $\left(10^{\prime} \times 10^{\prime}\right)$, but are not available as a time series [33]. The low-resolution $\left(30^{\prime} \times 30^{\prime}\right)$ climate time-series datasets were statistically downscaled to the higher $10^{\prime} \times 10^{\prime}$ 'resolution. Details of climate downscaling for the domain being investigated and assessment of the quality of the precipitation map are discussed in Poerbandono, et al. [34]. In Table 8, a summary of the quality assessment of the CRU's monthly precipitation maps as documented in Poerbandono, et al. [34] is given.

Table 7 Sources of land cover map.

\begin{tabular}{|c|c|c|c|}
\hline No. & Title of map & Source & Year \\
\hline & Natural forest cover of Java & {$[35]$} & 1891 \\
\hline 2. & Vegetation of Indonesia & US Dept. of Forest Service & 1950 \\
\hline & Land use map of Java Madura & FAO & 1963 \\
\hline 4. & Land use map & Ministry of Interior Indonesia & 1980 \\
\hline & Natural forest cover of Java & {$[35]$} & 1987 \\
\hline & MODIS land cover product & [36] & 2001-2006 \\
\hline
\end{tabular}

Table 8 Agreement between precipitation datasets and observations [34].

\begin{tabular}{lrr}
\hline \multicolumn{1}{c}{ Station } & $\boldsymbol{r}$ & \multicolumn{1}{c}{$\boldsymbol{\%}$} \\
\hline Tanjung Priok & 0.54 & 184 \\
Halim & 0.27 & 101 \\
Depok & 0.38 & 106 \\
Katulampa & 0.87 & 80 \\
\hline
\end{tabular}

\subsection{Calibration and Computation of Sediment Yield}

Calibration of SDAS was carried out for the upper Citarum catchment (UCC). The UCC covers an approximate area of $1,771 \mathrm{~km}^{2}$ [19] and is part of the Citarum watershed, which contributes to the Saguling reservoir (Figure 5). Monthly rainfall recorded in 2001 varied from 45 to $352 \mathrm{~mm}$ with an accumulated annual value of 2,200 mm [19]. The terrain is mountainous along its boundaries, with a flood plain in the centre of the basin. Regular monitoring of sediment discharge (yield) from the UCC has been made by the Water Resources Research and Development Centre of the Office of Public Works of 
West Java Province (Pusat Penelitian dan Pengembangan Sumberdaya Air, Kantor Pekerjaan Umum Propinsi Jawa Barat). The monitoring station is located in Nanjung (Figure 5). The magnitude of the annual sediment discharge is available from five years (Table 9).

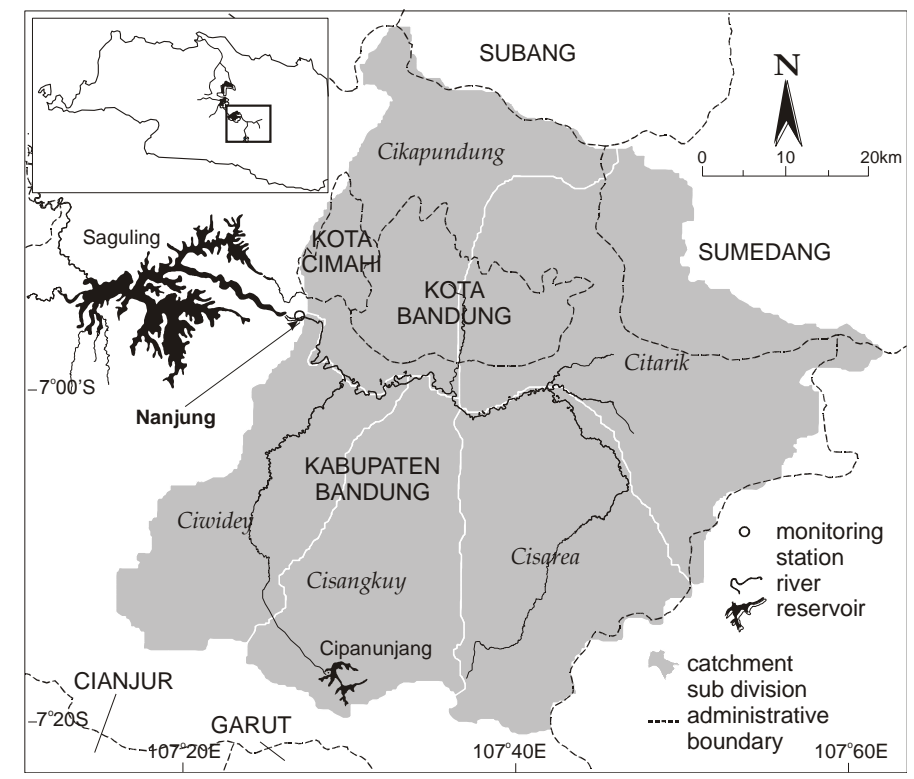

Figure 5 The upper Citarum catchment [19].

Table 9 Measured sediment yield in Nanjung station [19].

\begin{tabular}{cc}
\hline Year & $\boldsymbol{y}\left(\mathbf{\times 1 0}^{\mathbf{6}}\right.$ tons/year $)$ \\
\hline 1976 & 0.27 \\
1981 & 0.86 \\
1993 & 1.20 \\
2003 & 2.15 \\
2004 & 2.18 \\
\hline
\end{tabular}

In order to calibrate the SDAS output, we initially fixed the factors for inputs and constants (Table 10), and fit the computation results (i.e. annual yield of sediment) with the first two data from the observation series. Input factors that are fairly sensitive to sediment yield calculation (i.e. $P, C$ ) were left uncalibrated (equal to one). We assumed that rainfall duration $\left(t_{r}\right)$ and effective rainfall duration $\left(t_{e r}\right)$ were 20 and 7 hours per month respectively.

Table 10 Initial setting of factors for inputs and constants.

\begin{tabular}{lccccccc}
\hline Factor & $\boldsymbol{P}$ & $\boldsymbol{C}$ & $\boldsymbol{h}_{\boldsymbol{n}}$ & $\boldsymbol{h}_{\boldsymbol{h}}$ & $\boldsymbol{w}_{\boldsymbol{s}}$ & $\boldsymbol{t}_{\boldsymbol{r}}$ & $\boldsymbol{t}_{\boldsymbol{e r}}$ \\
\hline Value & 1 & 1 & 1 & 0.025 & 0.05 & 20 & 7 \\
\hline
\end{tabular}


The results show that while the computed sediment yield was fit to an epoch of observation data, a large discrepancy with the other epoch of observation data resulted. This could be due to the assumption of using constant and uniform hillslope flow depth and sediment grain size. As discussed by Boer \& Puigdefábregas [37], hillslope discharge and soil loss could be affected by variation in the spatial correlation structure of coupled vegetation cover and soil patterns alone. In addition to that, rainfall intensity and slope gradient play a contributing role. This suggests that the hillslope flow depth, which provides strong control on the sediment yield calculation, should vary with the variability of the type of land cover and precipitation. Hence, we verified the effect of changes in hillslope flow depth by carrying out a calculation of the sediment yield for the first two epochs and concluded that hillslope flow depth should change over time. We propose to represent this by relating hillslope flow depth $\left(h_{h}\right)$ to land cover $(C)$ :

$$
h_{h}=-1.944 C-0.2
$$

\section{$3 \quad$ Result and Discussion}

\subsection{Agreement between Computed and Observed Sediment Yield}

Figure 6 shows a comparison between the computed sediment yield using SDAS and the observed sediment yield. The observation data covered the years 1976, 1981, 1994, 2003 and 2004. It can be seen from Figure 6 that SDAS was capable of providing results in the same order of magnitude with respect to the observed sediment yield. SDAS computation could also accommodate the trend of increasing sediment yield. This indicates that time-dependent SDAS input can be well considered. The agreement between computed and observed sediment yield is shown in Table 11. It gives an average deviation of 7\%, with a coefficient correlation of 0.99 and an overall ratio of computed and observed magnitude of $111 \%$. When looking at the last two epochs, quite a discrepancy can be seen, especially in terms of overestimation.

The estimate of the hillslope flow depth is thought to contribute to the inaccuracy of the sediment yield calculation. Assuming that the change of flow depth is solely due to a change in land cover, as in Eq. (17), seems to be an oversimplification of the natural physical processes. It neglects the variability of soil patterns, rainfall intensity, and slope gradient. Calculation of yield of sediment assumes a constant and uniform sediment size. While sediment size has a strong influence on sediment yield computation, only one single epoch of soil type map was used here as source of sediment. Bearing in mind the limitations of accuracy of SDAS computation within the range of the period of 
calibration, we carried out a simulation of the watershed where the calibration was made for a decadal time range.

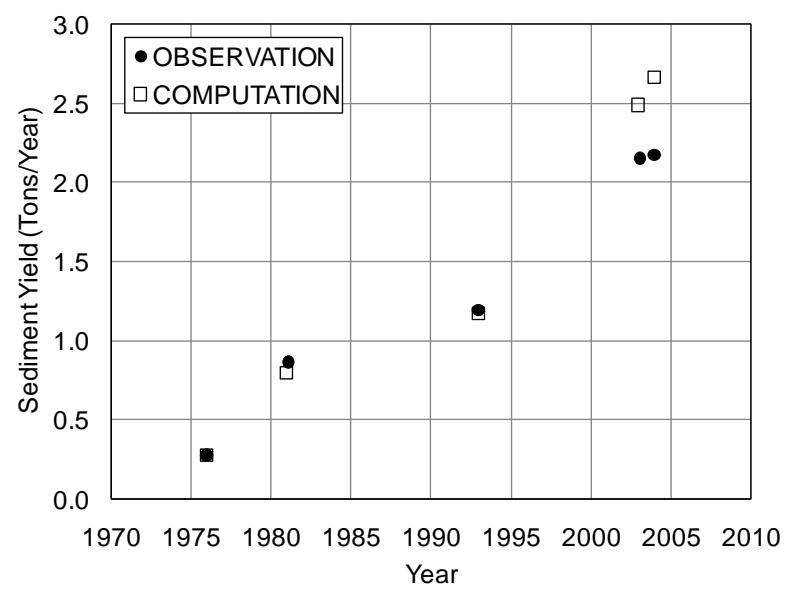

Figure 6 Comparison between computed and observed sediment yield.

Table 11 Comparison between computed and observed sediment yield.

\begin{tabular}{lccc}
\hline \multirow{2}{*}{ Year } & \multicolumn{2}{c}{$\boldsymbol{y}\left(\times \mathbf{1 0}^{\mathbf{6}}\right.$ tons/year $)$} & \multirow{2}{*}{ Discrepancy } \\
\cline { 2 - 3 } & Observed & Computed & \\
\hline $1976^{*}$ & 0.27 & 0.27 & N/A \\
1981 & 0.86 & 0.79 & $-8 \%$ \\
1993 & 1.20 & 1.17 & $-3 \%$ \\
2003 & 2.15 & 2.49 & $16 \%$ \\
2004 & 2.18 & 2.66 & $22 \%$ \\
\hline Average & 1.60 & 1.78 & $7 \%$ \\
\hline Note: ${ }^{*}$ This epoch was not considered in the assessment of agreement
\end{tabular}

\subsection{Simulation of Spatially Distributed Sediment Yield}

Selected representative results of the simulation are shown. Digital cartographic software is needed to generate a visual presentation of the SDAS output. SDAS delivers tabulated results in ASCII format and we used ESRI ArcGIS software to depict the spatial distribution of sediment yield. Analysis of coverage and change of erosion behavior in the investigated domain throughout the $20^{\text {th }}$ century were also made. In Figures 7 and 8, the spatial distributions of the sediment yield are given as overlays on the DEM. 


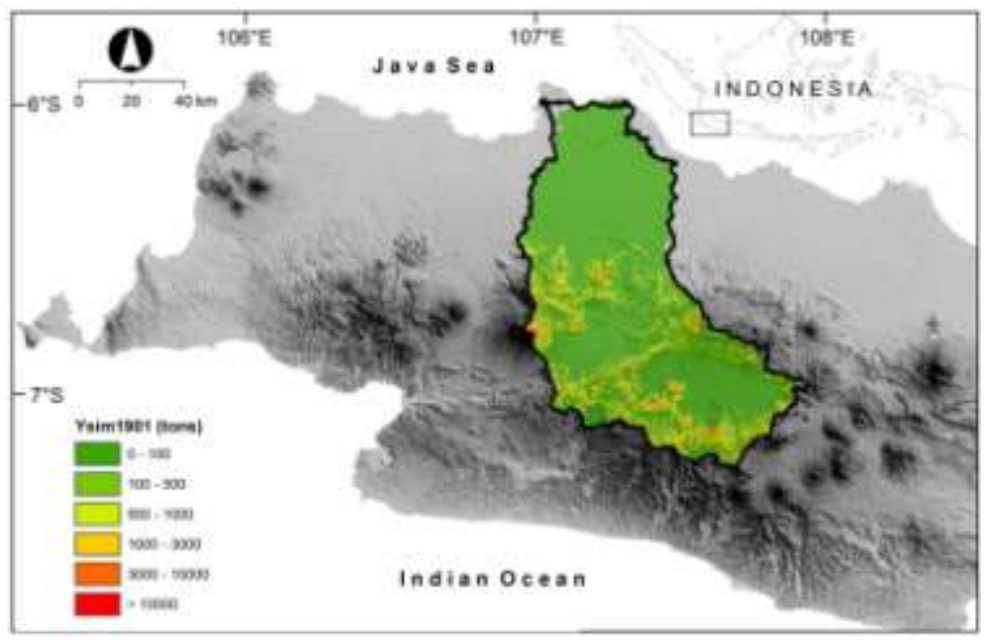

Figure 7 Sediment yield (y) distribution in 1901.

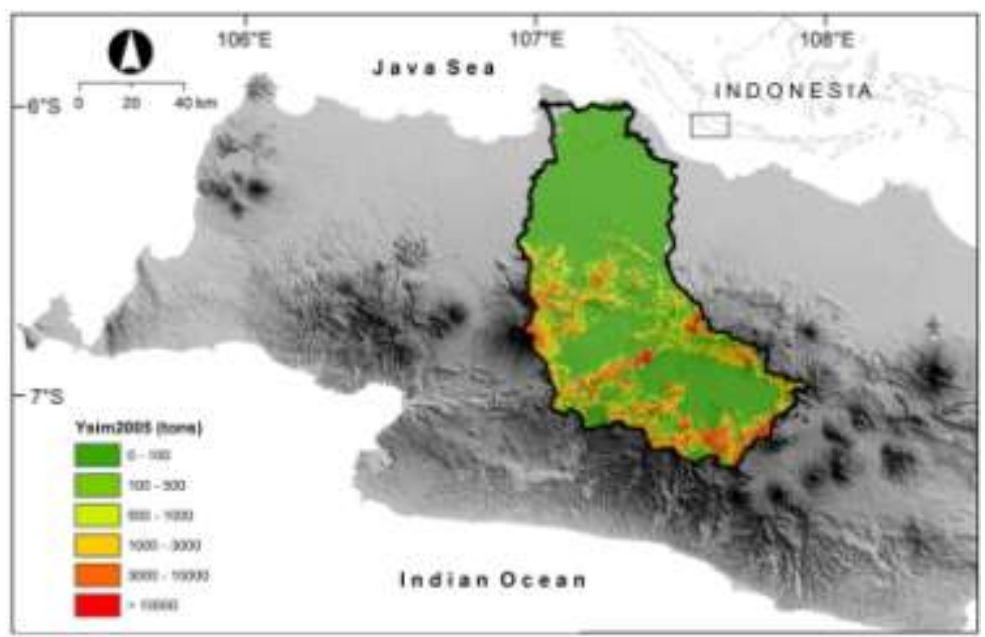

Figure 8 Sediment yield $(y)$ distribution in 2005.

In Table 12, areas experiencing normal erosion ( $y \leq 3,000$ tons/km2/year) and critical erosion ( $y>3,000$ tons/km2/year) are shown. Table 13 shows the maximum and mean yield of sediment computed for 2005 and 1901. Citarum experienced an increase of critically eroded areas and yields of sediment. While in 1901 only $0.4 \%$ of Citarum experienced critical erosion, in 2005 the extent of critical erosion has increased to $8.4 \%$. In the case of mean sediment yield, the increase of magnitude was found to be by a factor of 4 . Spatial changes in sediment yield throughout the 20th century can also be detected visually. In Figure 9 a map is shown that was generated by subtracting the sediment yield map for 1901 from that for 2005. Figure 9 illustrates how much the yield of 
sediment in the region had increased. A major increase of sediment yield is found predominantly in the upper watersheds. This is thought to be due to conversion of vegetated zones, e.g. forests, into bare land or plantation and agricultural areas.

Table 12 Area experiencing normal and critical erosion in \% of watershed area.

\begin{tabular}{lrrr}
\hline Type & $\boldsymbol{y}$ (tons) & $\mathbf{1 9 0 1}$ & $\mathbf{2 0 0 5}$ \\
\hline Normal & $\leq 3,000$ & 99.6 & 91.6 \\
Critical & $>3,000$ & 0.4 & 8.4 \\
\hline Change & & & 21.0 \\
\hline Note: & \\
\hline
\end{tabular}

Table 13 Total annual sediment yield in 1901 and 2005 in tons $/ \mathrm{km}^{2} / y e a r$.

\begin{tabular}{cccccc}
\hline \multicolumn{2}{c}{1901} & \multicolumn{2}{c}{2005} & \multicolumn{2}{c}{ Change $^{\text {a) }}$} \\
\hline Max. & Mean & Max. & Mean & Max. & Mean \\
\hline 6,485 & 204 & 103,900 & 917 & 16.0 & 4.5 \\
\hline Note: ${ }^{\text {a) }}$ factor of increase & & & &
\end{tabular}

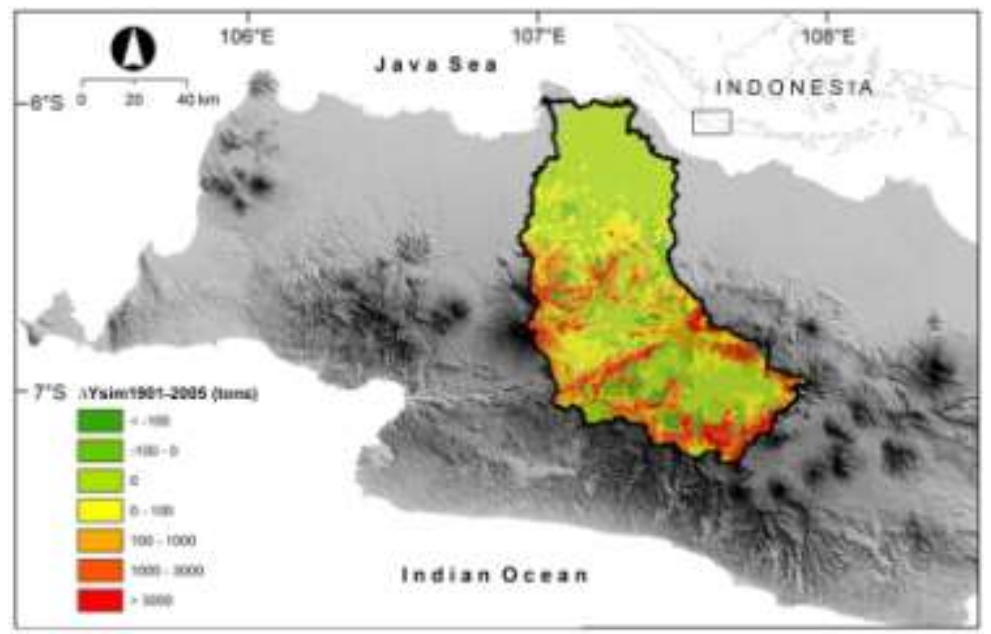

Figure 9 Changes of sediment yield distribution between 1901 and 2005.

The computation results from SDAS output as given in Table 12 and Table 13, as well as classification of erosion states and the corresponding changes from two different epochs indicate cases that could be useful for evaluation and spatial planning of watershed management. It should be noted that these results were limited by the assumptions used in SDAS calculation. Overestimation of the results by up to $22 \%$ can be expected for recent results of simulation. 


\section{Conclusion}

SDAS is developed as a spatial tool for simulation of watershed erosion and is composed of the following model components: terrain model, spatial units, and computation of measures of watershed erosion (erosion rate, sediment delivery ratio, and sediment yield). At the present stage, SDAS is available as a licensefree computer application for academic training and educational purposes at the undergraduate level. It assists class teaching and exercises for students. The capability of SDAS to perform what-if computations within a range of climate change periods (105 years) in the Citarum river basin, with changes of precipitation on a monthly basis and land cover in a single watershed, was discussed in this paper. The applicability of SDAS is limited by the complexity of data preparation, primarily in setting up uniform input maps (DEM, land cover, soil type, precipitation) from various secondary sources. As SDAS is not facilitated by a presentation component, additional software (i.e. spreadsheet, graphic, mapping) for specific analyses and visual presentation is needed. SDAS has indeed delivered substantial information on spatial erosion rate and sediment yield, which were computed based on the latest knowledge on spatial modeling of watershed erosion. SDAS allows presentation of the impact of changes in land cover for the case of the Citarum river basin over the course of a century for consideration by policy makers in watershed management.

\section{Acknowledgements}

This study is a collaborative research project between ITB and the Institute for Environmental Studies of VU University, Amsterdam (IVM-VU). The Royal Dutch Academy of Arts and Sciences (KNAW) provides the mobility funding for the exchange of academics. Dr. Philip J. Ward of IVM-VU is acknowledged for his advice. Mr. R.A. Muttaqin, Mr. B.M. Habibi, and Mr. A.R. Hakim were involved in development. This manuscript has benefited from anonymous reviewers.

\section{References}

[1] Xie, P. \& Arkin, P.A., Global Precipitation, Bull. Amer. Meteor. Soc., 78, pp. 2539-58, 1997.

[2] Manton, M.J., Della-Marta, P.M., Haylock, M.R., Hennessy, K.J., Nicholls, N., Chambers, L.E., Collins, D.A., Daw, G., Finet, A., Gunawan, D., Inape, K., Isobe, H., Kestini, T.S., Lefale, P., Leyuk, C.H., Lwinl, T., Maitrepierre, L., Ouprasitwong, N., Page, C.M., Pahalado, J., Plummer, M., Salinger, M.J., Suppiah, R., Tran, V.L., Trewin, B., Tibig, I. \& Yee, D., Trends in Extreme Daily Rainfall and Temperature in Southeast Asia and the South Pacific: 1961-1998, Int. J. Climatol., 21, pp. 269-284, 2001. 
[3] Bell, G.D., Halpert, M.S., Ropelewski, C.F., Kousky, V.E., Douglas, A.V., Schnell, R.C. \& Gelman, M.E., Climate Assessment for 1998, Bull. Amer. Meteor. Soc., 80(5), pp. S1-S48, 1997.

[4] Texier, P., Floods in Jakarta: When the Extreme Reveals Daily Structural Constraints and Mismanagement, Disaster Prevention and Management 17(3), pp. 358-372, 2008.

[5] Yin, H. \& Li, C., Human Impact on Floods and Flood Disasters on the Yangtze River, Geomorphology, 41(2-3), pp. 105-109, 2001.

[6] Nicholls, R.J., Hoozemans \& Marchand, M., Increasing Flood Risk and Wetland Losses due to Global Sea-Level Rise: Regional and Global Analyses, Global Environmental Change, 9(1), pp. S69-S87, 1999.

[7] Leary, N.A., A Framework for Benefit-Cost Analysis of Adaptation to Climate Change and Climate Variability, Mitigation and Adaptation Strategies for Global Change, 4, pp. 307-318, 1999.

[8] Fankhauser, S., Smith, J.B. \& Tol, R.S.J., Weathering Climate Change: Some Simple Rules to Guide Adaptation Decisions, Ecological Economics, 30(1), pp. 67-78, 1999.

[9] Lin, C.Y., Lin, W.T. \& Chou, W.C., Soil Erosion Prediction and Sediment Yield Estimation: The Taiwan Experience, Soil and Til. Res., 68(2), pp.143-152, 2002.

[10] He, C., Integration of Geographic Information Systems and Simulation Model for Watershed Management, Environmental Modelling and Software, 18(8-9), pp. 809-813, 2003.

[11] Cohen, M.J. \& Shepherd, K.D., Empirical Reformulation of the Universal Soil Loss Equation for Erosion Risk Assessment in a Tropical Watershed, Geoderma, 124(3-4), pp. 235-252, 2005.

[12] Baigorria, G.A. \& Romero, C.C., Assessment of Erosion Hotspots in a Watershed: Integrating the WEPP Model and GIS in a Case Study in the Peruvian Andes, Environmental Modelling and Software, 22(8), pp. 1175-1183, 2007.

[13] Brown, D.G., Bian, L. \& Walsh, S.J., Response of a Distributed Watershed Erosion Model to Variations in Input Data Aggregation Levels, Computers and Geosciences, 19(4), pp. 499-509, 1993.

[14] Mitra, B., Scott, H.D., Dixon, J.C. \& McKimmey, J.M., Applications of Fuzzy Logic to the Prediction of Soil Erosion in a Large Watershed, Geoderma, 86(3-4), pp. 183-209, 1998.

[15] Arnold, J.G., Srinivasan, R., Muttiah, R.S. \& Williams, J.R., Large Area Hydrologic Modeling and Assessment, Part 1: Model Development, J. Am. Water Resources Association, 34(1), pp. 73-89, 1998.

[16] Lu, H., Moran, C.J. \& Prosser, I.P., Modeling Sediment Delivery Ratio over the Murray Darling Basin, CSIRO Land and Water, Elsevier, Canberra, 2003. 
[17] Wischmeier, W.H. \& Smith, D.D., Predicting Rainfall Erosion Losses-A Guide to Conservation Planning, US Dept. Agricultural Handbook, 537, 1978.

[18] Sivapalan, M., Jothityankuun, C., Menabde, M., Linearity and Nonlinearity of Basin Response as a Function of Scale: Discussion of Alternative Definitions, Water Resources Research, 38(2), pp. 4.1-4.5, 2002.

[19] Poerbandono, Basyar, A. \& Harto, A.B., Spatial Modeling of Sediment transport over the Upper Citarum Catchment, ITB J. Eng. Sci., 38B(1), pp. 11-28, 2006.

[20] USDA-SCS, National Engineering Handbook, Hydrology, Section 4, US Dept. of Agriculture, Soil Conservation Service, Washington, 1972.

[21] Renard, K.G., Foster, G.R., Weesies, G.A., McCool, D.K. \& Yoder, D.C., Predicting Soil Erosion by Water: A Guide to Conservation Planning with the Revised Universal Soil Loss Equation (RUSLE), US Dep. Agriculture, 703, 1997.

[22] Trahan, N., Modeling Sediment and Contaminant Pathways to the Cedar River, Jones, Edmunds \& Associates, Florida, 2003.

[23] Erosion and Sedimentation Working Group, Erosion and Sedimentation Study in Teluk Balikpapan Watershed, East Kalimantan, Coastal Project Technical Report (in Indonesian), TE-02/13-I, CRC/URI, Jakarta, 2002.

[24] Kartasapoetra, Soil and Water Conservation Engineering (Text in Indonesian), Rineka Cipta, Jakarta, 1991.

[25] DHV Consulting Engineers, Study on Catchment Preservation and on Environmental Impact of the Water Supply Projects of Bandung and Sukabumi, Ministry of Public Works, Directorate General Cipta Karya, 1989.

[26] Tarboton, D.G., A New Method for the Determination of Flow Directions and Contributing Areas in Grid Digital Elevation Models, Water Resources Research, 33(2), pp. 309-319, 1997.

[27] Jenson, S.K. \& Domingue, J.O., Extracting Topographic Structure from Digital Elevation Data for Geographic Information System Analysis, Photogrammetric Engineering and Remote Sensing, 54(11), pp. 15931600, 1988.

[28] Strahler, A.N, Hypsometric (Area-Altitude) Analysis of Erosional Topology, Geological Society of America Bulletin, 63(11), pp. 11171142, 1952.

[29] Strahler, A.N., Quantitative Analysis of Watershed Geomorphology, Transactions of the American Geophysical Union, 8(6), pp. 913-920, 1957.

[30] Lu, H., Moran, C.J., Prosser, I.P., Raupach, M.R., Olley, J. \& Petheram, C., Hillslope Erosion and Sediment Delivery: A Basin Wide Estimation at Medium Catchment Scale, Technical Report 15/03, CSIRO, pp. 56, 2003. 
[31] ERSDAC, ASTER GDEM Ver. 1, http://www.gdem.aster.ersdac.or.jp, 2009. (26 September 2013)

[32] University of East Anglia Climate Research Unit (CRU), CRU Datasets, British Atmospheric Data Centre, http://badc.nerc.ac.uk/browse/badc/cru, 2008. (8 July 2011).

[33] New, M., Lister, D., Hulme, M. \& Makin, I., A High-Resolution Dataset of Surface Climate Over Global Land Areas, Climate Research, 21, pp. 125, 2002.

[34] Poerbandono, Ward, P.J. \& Julian, M.M., Set Up and Calibration of a Spatial Tool for simulating latest Decades Flow Discharges of the Western Java: Preliminary Results and Assessments, ITB J. Eng. Sci., 41B(1), pp. 50-64, 2009.

[35] Whitten, T., Soeriaatmadja, R.E. \& Afiff, S.A., The Ecology of Java and Bali, Periplus Editions, Dalhousie University, 1996.

[36] Oak Ridge National Laboratory Distributed Active Archive Center, Oak Ridge, Tennessee, http://daac.ornl.gov/S2K/safari.html, 2001. (27 January 2006).

[37] Boer, M. \& Puigdefábregas, J., Effects of Spatially Structured Vegetation Patterns on Hillslope Erosion in a Semiarid Mediterranean Environment: a Simulation Study, Earth Surface Processes and Landforms, 30, pp. 149167, 2005. 